\title{
Effects of the 1997-1998 El Niño on early-juvenile Pacific hake Merluccius productus: age, growth, abundance, and diet in coastal nursery habitats
}

\author{
Jill J. Grover ${ }^{1, *}$, Troy W. Buckley ${ }^{2}$, David Woodbury ${ }^{3, * *}$ \\ ${ }^{1}$ College of Oceanic and Atmospheric Sciences, Oregon State University, Hatfield Marine Science Center, Newport, \\ Oregon 97365, USA \\ ${ }^{2}$ Alaska Fisheries Science Center, National Marine Fisheries Service, 7600 Sand Point Way N.E., F\AKC2, Seattle, \\ Washington 98115, USA \\ ${ }^{3}$ Southwest Fisheries Science Center, National Marine Fisheries Service, 3150 Paradise Dr., Tiburon, California 94920, USA
}

\begin{abstract}
The effects of anomalous oceanographic conditions on growth, abundance, spawn-date distributions, and diet of early-juvenile Pacific hake Merluccius productus were examined in nursery grounds off the coast of central California, USA. Spring collections from 2 consecutive years of El Niño conditions, 1997 and 1998, 1 year of La Niña conditions, 1999, and 1 non-anomalous year, 1995, were examined. During spring of 1997, the first year of the El Niño event, early-juvenile hake appeared to compensate for anomalous ocean conditions by ingesting a wider variety of zooplankton taxa and sizes. Continuation of El Niño conditions through spring 1998 appeared to have a strong impact on the 1998 year class. Very low levels of macrozooplankton biomass in February 1998 resulted in poor growth and reduced survival of hake from early spawns.
\end{abstract}

KEY WORDS: Hake $\cdot$ El Niño effects $\cdot$ Age and growth $\cdot$ Food habits

Resale or republication not permitted without written consent of the publisher

\section{INTRODUCTION}

Off California, Oregon, and Washington, Pacific hake (also known as Pacific whiting) Merluccius productus is a dominant finfish species in coastal habitats, commercially as well as ecologically (Methot \& Dorn 1995). The large biomass of Pacific hake affords it a key position as both predator and prey in the coastal food web (Livingston \& Bailey 1985).

Year classes of Pacific hake exhibit hundredfold variation in abundance (Methot \& Dorn 1995), with much of the variability in recruitment determined by oceanographic conditions in nearshore nursery habitats during the first few months of life (Hollowed 1992). Good

\footnotetext{
*E-mail: jill.grover@oregonstate.edu

** Present address: National Marine Fisheries Service, Western Administrative Services Center, 777 Sonoma Ave., Santa Rosa, California 95404-6515, USA
}

recruitment and strong year classes of Pacific hake occur when periods of weak upwelling and reduced offshore transport of eggs and larvae in early winter are followed by strong upwelling in March (Bailey 1981, Bailey \& Francis 1985, Hollowed \& Bailey 1989). Warm ocean conditions tend to produce stronger year classes of Pacific hake (Bailey \& Francis 1985). The strongest year classes on record occurred in 1980 and 1984, during a period of warm ocean conditions (Hunter \& Hollowed 1997). The recent occurrence of several El Niño events in coastal waters of the NE Pacific Ocean, during springtime, could be superficially interpreted as beneficial to Pacific hake stocks. However, inasmuch as each El Niño event has a unique signature (Huyer \& Smith 1985), warm El Niño ocean conditions do not universally yield strong year classes of Pacific hake (Bailey \& Francis 1985).

Prior to 1997, one of the strongest El Niño events on record warmed sea surface temperatures in the Pacific 
Ocean off the West Coast of the USA during winter and spring of 1982-1983. The 1982-1983 El Niño conditions were manifested through increases in sea surface temperature (SST), sea level, and poleward currents, reductions in salinities and coastal upwelling, and a depression of the thermocline (Fiedler 1984, Huyer \& Smith 1985, McGowan 1985). By all measures (Stauffer 1985, Hollowed \& Bailey 1989, Dorn \& Methot 1990, Hollowed 1992), 1983 El Niño conditions yielded a poor year class of Pacific hake. Similarly, a comparison of early-juvenile Pacific hake growth and abundance in 1992, an El Niño year, with 3 previous years revealed that the 1992 class had the poorest growth rate, and was the least abundant (Woodbury et al. 1995). However, in 1993, a second consecutive spring of El Niño conditions in nursery habitats (Hayward et al. 1994) produced the most recent strong year class of Pacific hake (Dorn \& Saunders 1997).

Coastal waters off California and Baja California that encompass the historical spawning venues and nursery grounds of Pacific hake (Bailey et al. 1982) experienced unusually large, El Niño-driven anomalies in both physical and biological conditions from January 1997 through to summer 1998. The 1997-1998 El Niño event was as strong as the 1982-1983 event, and was closely monitored (Lynn et al. 1998, Freeland 2000, Hayward 2000). From January 1997 to autumn 1998, El Niño conditions in the NE Pacific Ocean included record SST anomalies, record deep temperature anomalies, record sea-level anomalies, record low midwinter mixed layer depths, and very low primary production (Lynn et al. 1998, Freeland 2000, Hayward 2000). Delayed and decreased upwelling resulted in a reduction in biomass and production of zooplankton (Peterson 1999). The continuation of anomalous El Niño conditions through the winter of 1997-1998, resulted in impoverished plankton assemblages in nursery grounds in late winter ${ }^{1}$ and spring of 1998. In February and April 1998, California Cooperative Oceanic Fisheries Investigations (CalCOFI) cruises recorded the lowest biomass of macrozooplankton in the entire CalCOFI time series of cruise data (1951 to present) (Lynn et al. 1998, Hayward et al. 1999, Bograd et al. 2000). As a result, considering the trophic dilemmas facing larvae and early juveniles in coastal nursery habitats may be critical to understanding the impact of protracted anomalous El Niño conditions on zooplanktivorous, early-juvenile Pacific hake.

\footnotetext{
${ }^{1}$ El Niño watch, advisory 1998-01, and 1998-02. Coastal ocean mean SST $\left({ }^{\circ} \mathrm{C}\right)$ and deviation from normal, January and February 1998. NOAA/NESDIS, CoastWatch West Coast, La Jolla, CA 92038-0271. http:\lcwatchwc.ucsd.edu/ cwatch.html
}

Within $2 \mathrm{yr}$, SSTs in the California Current region dropped from the warmest temperatures on record, during peak El Niño conditions in 1998, to low temperatures that had not been observed in decades, during La Niña conditions in 1999 (Hayward et al. 1999, Bograd et al. 2000). The El Niño conditions of 1998 (warm SST, low productivity) created a veritable biological drought. Macrozooplankton rebounded greatly in January and April 1999, in response to record upwelling during the La Niña conditions (cool SST, high productivity) (Bograd et al. 2000).

The objective of this study was to ascertain the effects of anomalous oceanographic conditions on earlyjuvenile Pacific hake Merluccius productus through an examination of abundance, growth rates, spawn-date distributions, and diet in coastal nursery grounds. This study utilized collections from 2 consecutive years of El Niño conditions, 1997 and 1998, 1 year of La Niña conditions, 1999, and 1 non-anomalous year, 1995. Ontogenetic differences in diet were also considered.

\section{MATERIALS AND METHODS}

During juvenile rockfish surveys conducted by the Southwest Fisheries Science Center, NOAA/NMFS, from the RV 'David Starr Jordan', early-juvenile Pacific hake were collected in nursery grounds off California, in spring, from 1986 to 1999 (Fig. 1). The surveys were designed to sample the pelagic nearshore zone from Cypress Point, California $\left(36^{\circ} 35^{\prime} \mathrm{N}\right)$, to Bodega Bay, California $\left(38^{\circ} 20^{\prime} \mathrm{N}\right)$, out to a distance of $55 \mathrm{~km}$ (Wyllie Escheverria et al. 1990, Sakuma \& Ralston 1997). Collections of early-juvenile Pacific hake were made at night (between 20:30 and 06:00 h) at standard stations and depths, using a modified Cobb midwater trawl, with a $1.3 \mathrm{~cm}$ mesh liner. Trawls lasted $15 \mathrm{~min}$ at depth. Earlyjuvenile Pacific hake were sorted and enumerated at sea. All specimens that were used for otolith analysis were frozen at sea. Specimens that were used for dietary analyses were frozen at sea, later defrosted into $10 \%$ Formalin for $24 \mathrm{~h}$, and then transferred into $70 \%$ ethanol, except in 1995, when specimens were fixed in $10 \%$ Formalin at sea, and later transferred into $70 \%$ ethanol.

Abundance values were based on the number of specimens collected at a depth of $30 \mathrm{~m}$, during 3 replicate sweeps of 36 standard stations, from mid-May to mid-June in the survey area from 1986 to 1998. Additionally, length frequencies, growth rates, and spawn dates were determined for juvenile Pacific hake from 1994 to 1998. Pacific hake from each haul were either enumerated directly or estimated through subsampling when catches were large. In the laboratory, fish were measured to the nearest $0.1 \mathrm{~mm}$ standard length (SL). A maximum of 150 fish per haul was measured. 
For each year, over the size range encountered, Pacific hake were selected for daily age analysis at 2 to $4 \mathrm{~mm}$ intervals. Sagittal otoliths were removed, and adhered to slides, sulcus up, with clear nail polish. Otoliths were prepared for microscopic viewing using hydrochloric acid to remove excess otolith tissue. A compound microscope with $40 \times$ and $100 \times$ objectives was interfaced with a digitizer, monitor, and computer (Woodbury \& Ralston 1991). Daily increments were measured and entered into the computer. Normally, only 1 otolith was read. Growth rates were examined using an analysis of covariance (ANCOVA) of age and SL, by year. A fixed-intercept, variable-slope linear model in semi-log space was fit to the age and length data.

Back-calculated spawn dates of the fish that survived until the time of sampling were obtained using a linear model. An age-length relationship was estimated from a subsample of aged fish from each year. Regression equations were then used to estimate the ages of all fish preserved from standard stations during the cruises (Woodbury et al. 1995). Based on ambient temperatures encountered off the California coast during the larval stage, Bailey (1982) estimated that eggs hatch in $5 \mathrm{~d}$, and the first daily ring is formed $3 \mathrm{~d}$ later. Therefore, $8 \mathrm{~d}$ were added to the otolith-increment estimated age of each fish to obtain age from spawning. Ages were subtracted from capture dates to yield spawn dates.

Collections from 1995, 1997, 1998 and 1999 were utilized to examine diet. For each specimen used in the dietary analyses, after the SL was recorded, the stomach was removed. Stomach contents were dissected out and examined. Prey items were identified to the lowest possible taxon, enumerated, and their lengths and widths were measured.

Stomach contents were evaluated by considering incidence of feeding, quantity, size, and composition of ingested prey. Diet was analyzed in terms of numerical composition $(\% \mathrm{~N})$, volumetric composition $(\% \mathrm{~V})$, and frequency of occurrence (\%FO). Prey size selection was examined by measuring widths of ingested prey items, and prey volumes were calculated based on prey dimensions, assuming a spheroidal geometry.

Dietary analyses were interpreted as a function of juvenile size (i.e. by $10 \mathrm{~mm}$ size classes), and year of collection. The diets of early-juvenile Pacific hake in 2 years of El Niño conditions, 1997 and 1998, were compared with the diets in a year of non-anomalous ocean conditions, 1995, and a year of La Niña conditions, 1999. Comparisons such as the number and size of prey that were ingested were made using a KruskalWallace 1-way ANOVA test. Some comparisons utilized the chi-square test for heterogeneity or independence (Conover 1980).
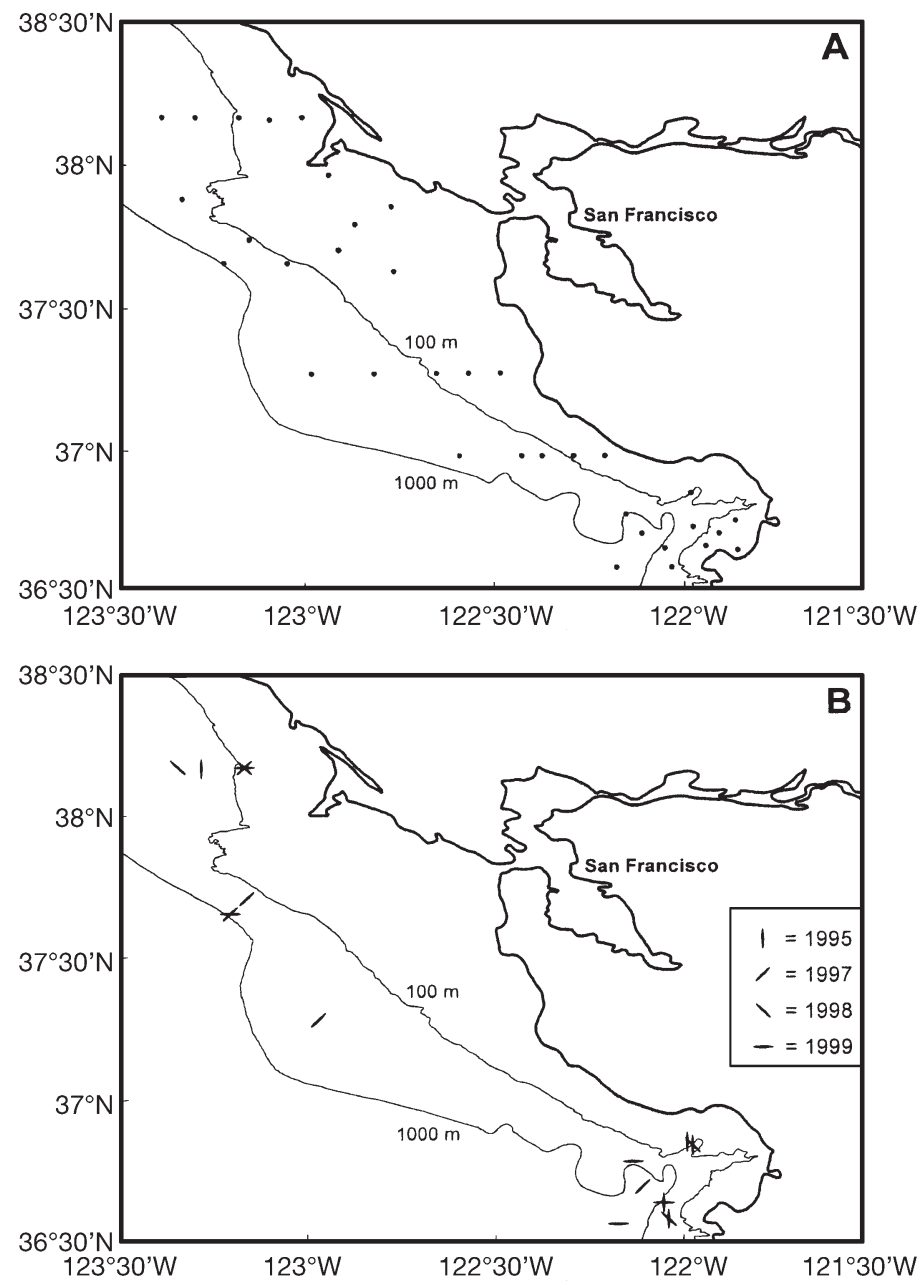

Fig. 1. Location of trawl stations, off central California, where early-juvenile Pacific hake were collected: (A) standard stations used to examine age, growth, and abundance, (B) stations used in dietary analyses, by year

All available specimens from 1995 were examined ( $\mathrm{n}=121$ ). In 1997 and 1999, 50 specimens were examined per haul, from 5 hauls $(\mathrm{n}=250)$. In 1998, 60 specimens were examined per haul, from 4 hauls $(\mathrm{n}=240)$. The shift in sampling for 1998 was made to improve the balance between size classes, as a fifth haul contained only small specimens.

\section{RESULTS}

\section{Abundance of early-juvenile Pacific hake}

A comparison of the number of early-juvenile Pacific hake collected during spring in coastal nursery grounds off central California shows that catches varied from year to year by orders of magnitude (Table 1). Col- 


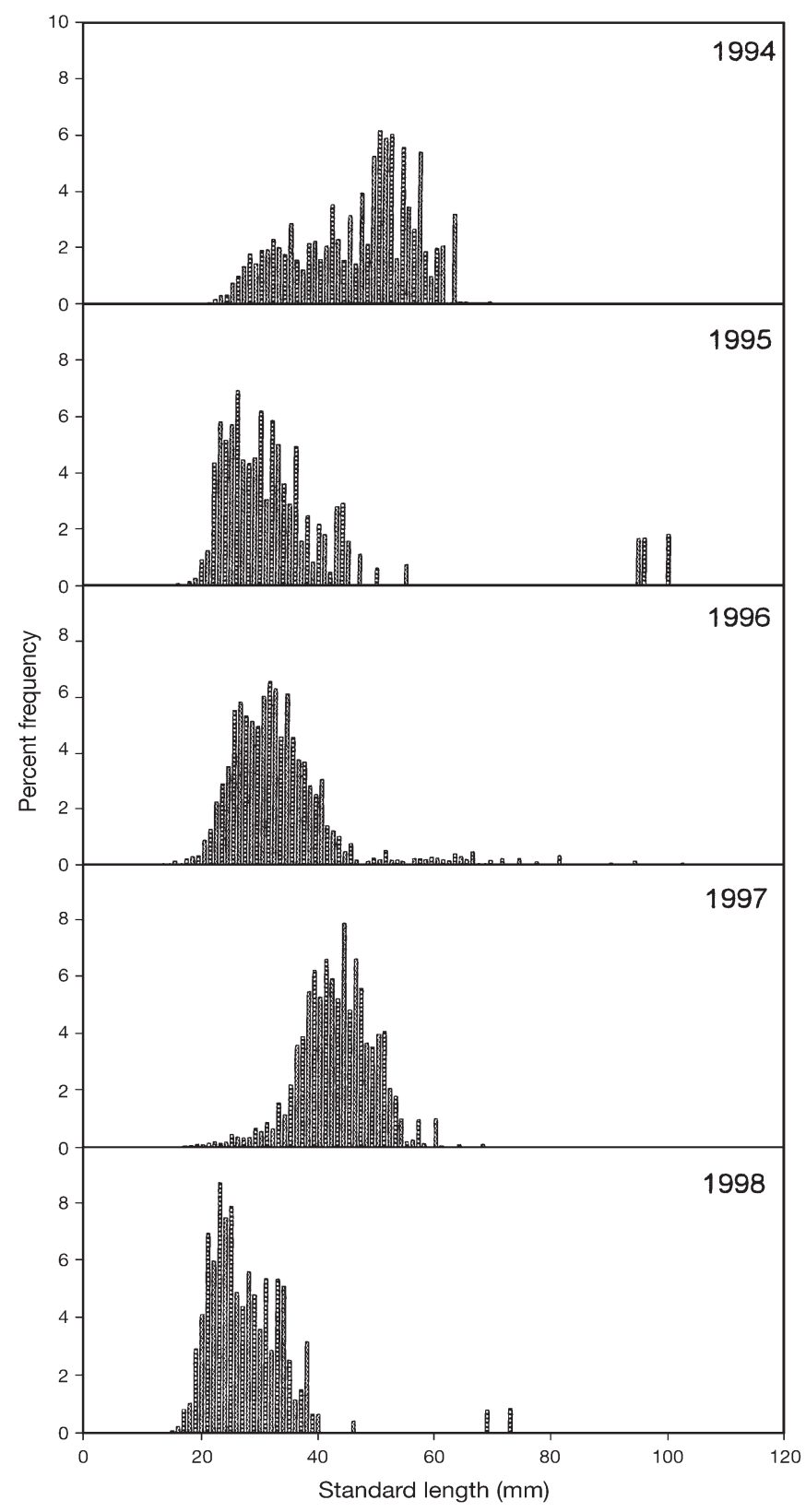

Fig. 2. Merluccius productus. Annual length-frequency distributions of early juveniles, by year
Table 1. Merluccius productus. Abundance of early juveniles collected in spring off California at standard stations and depths (S. Ralston unpubl. data) Note: these data were not adjusted for mortality, i.e. larger fish were not weighted more than smaller fish. Adjusting for mortality would tend to increase the numbers in good years and reduce the numbers in poor years

\begin{tabular}{|c|c|c|c|c|}
\hline Year & $\begin{array}{c}\text { Total } \\
\text { number } \\
\text { collected }\end{array}$ & $\begin{array}{c}\text { Rank (1 = } \\
\text { highest) }\end{array}$ & $\begin{array}{c}\text { Tows with } \\
\text { early-juvenile } \\
\text { hake }(\%)\end{array}$ & $\begin{array}{l}\text { Oceanographic } \\
\text { anomalies } \\
\text { (in spring) }\end{array}$ \\
\hline 1986 & 10405 & 4 & 52.2 & \\
\hline 1987 & 165693 & 2 & 73.6 & \\
\hline 1988 & 58700 & 3 & 81.0 & \\
\hline 1989 & 857 & 12 & 47.0 & \\
\hline 1990 & 6708 & 7 & 46.5 & \\
\hline 1991 & 5931 & 8 & 70.2 & \\
\hline 1992 & 1104 & 11 & 46.6 & El Niño \\
\hline 1993 & 167920 & 1 & 69.0 & El Niño \\
\hline 1994 & 7519 & 6 & 70.8 & \\
\hline 1995 & 580 & 14 & 46.2 & \\
\hline 1996 & 5718 & 10 & 64.2 & \\
\hline 1997 & 5914 & 9 & 61.2 & El Niño \\
\hline 1998 & 787 & 13 & 39.4 & El Niño \\
\hline 1999 & 8508 & 5 & 63.7 & La Niña \\
\hline
\end{tabular}

lections from 1987 and 1993 yielded very large catches, while the poorest catch occurred in 1995. The percentage of tows at standard stations that contained earlyjuvenile Pacific hake tended to reflect the trend seen in total catches: good years had values $>65 \%$, while poor years had values $<50 \%$. The lowest frequency was seen in 1998, when only $39.4 \%$ of tows contained earlyjuvenile Pacific hake. During the most recent 2 yr El Niño event, Pacific hake were less abundant in 1998, accounting for only $13.3 \%$ of the number collected in 1997. The number of early-juvenile Pacific hake collected in the spring of 1998, a second consecutive El Niño spring, was the second lowest in $14 \mathrm{yr}$ of collections, and was $<0.5 \%$ of the number collected in spring 1993 (Table 1), which was also a second consecutive spring of El Niño conditions. The abundance of earlyjuvenile Pacific hake increased during 1999 La Niña conditions, ranking fifth among years of collections.

Table 2. Merluccius productus. Definition of parameters and variables in a linear model of early-juvenile growth, generated in an ANCOVA fixed-intercept, variable-slope analysis: $\ln (\mathrm{SL})=a+b(\mathrm{Age})$, predicted length at age $100 \mathrm{~d}$, and growth rate at age; by year, where $\mathrm{n}=$ sample size

\begin{tabular}{|c|c|c|c|c|c|c|c|c|}
\hline \multirow[t]{2}{*}{ Year } & \multirow[t]{2}{*}{$\mathrm{n}$} & \multirow[t]{2}{*}{ Intercept $(a)\left(\log _{\mathrm{e}}\right)$} & \multirow[t]{2}{*}{ Slope $(b)\left(\log _{\mathrm{e}}\right)$} & \multirow[t]{2}{*}{ Length at $100 \mathrm{~d}(\mathrm{~mm})$} & \multicolumn{4}{|c|}{ Growth rate $\left(\mathrm{mm} \mathrm{d}^{-1}\right)$ at age $(\mathrm{d})$ : } \\
\hline & & & & & 50 & 75 & 100 & 125 \\
\hline $1994-1998$ & & 2.0938 & & & & & & \\
\hline 1994 & 30 & & 0.0143 & 34.2 & 0.24 & 0.34 & 0.49 & 0.69 \\
\hline 1995 & 34 & & 0.0136 & 31.9 & 0.22 & 0.31 & 0.43 & 0.60 \\
\hline 1996 & 35 & & 0.0140 & 33.2 & 0.23 & 0.32 & 0.46 & 0.65 \\
\hline 1997 & 51 & & 0.0159 & 40.3 & 0.29 & 0.43 & 0.64 & 0.95 \\
\hline 1998 & 24 & & 0.0150 & 36.9 & 0.26 & 0.38 & 0.55 & 0.80 \\
\hline
\end{tabular}




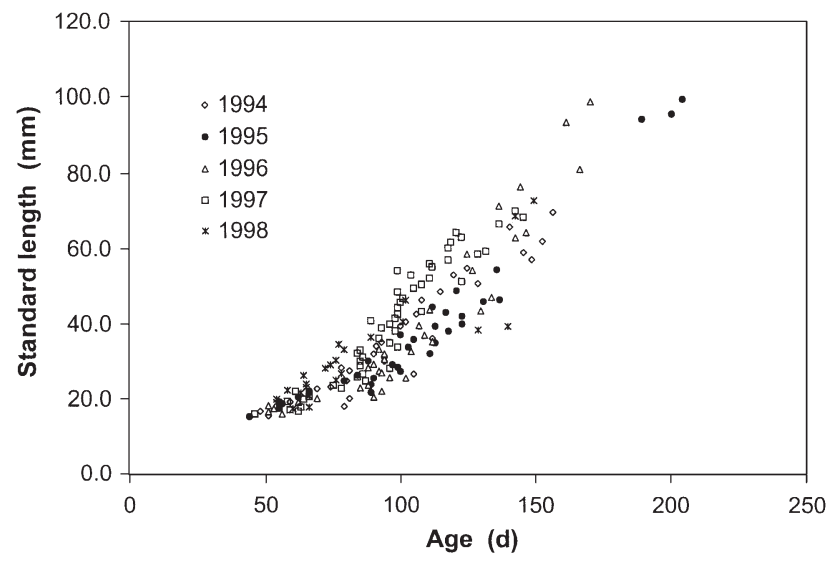

Fig. 3. Merluccius productus. Plot of early-juvenile standard lengths as a function of age, by year

\section{Size distribution of early-juvenile Pacific hake}

The size distribution of Pacific hake in spring collections varied from year to year (Fig. 2). All betweenyear comparisons of size distributions, except between 1995 and 1998, and between 1995 and 1996, were significantly different $(\mathrm{p}<0.001$, Kolmogorov-Smirnov test). The size distributions in 1997 and 1998 were particularly disparate. Early-juvenile Pacific hake that were collected during spring 1998 were the smallest in the 5 yr series of collections.

\section{Growth rates}

From 1994 to 1998, growth rates were calculated from a linear model in semi-log space, generated in an ANCOVA fixed-intercept, variable-slope analysis: $\ln (\mathrm{SL})=$ $\mathrm{a}+\mathrm{b}$ (Age) (Table 2). There were significant betweenyear differences in slope $(p<0.0001)$, total $r^{2}=0.8884$. In terms of slope, predicted length at $100 \mathrm{~d}$, and growth rate (Table 2), early-juvenile Pacific hake grew fastest during the first year of El Niño conditions, in 1997, and slowest during 1995. In between these extremes, growth rates ranked as follows: $1998>1994>1996$.

Two striking observations were obtained from plotting length versus age (Fig. 3). First, there was a paucity of specimens older than 110 d from 1998 ( $\mathrm{n}=4)$ compared with all other years ( $\mathrm{n}=11$ to 15$)$. Secondly, in the 38.0 to $40.0 \mathrm{~mm}$ SL size range, a great disparity was seen in age. The 3 youngest specimens, at 93, 96, and $98 \mathrm{~d}$, were all collected in 1997 . The 2 oldest specimens, at 129 and 140 d, were both collected in 1998. Although the age difference between the oldest and youngest specimens in this size range was $47 \mathrm{~d}$, the size difference was merely $0.5 \mathrm{~mm} \mathrm{SL}$, reflecting poor growth early in 1998.

\section{Spawn dates}

A comparison of the distributions of spawn dates from 1994 to 1998 (Fig. 4) revealed that spawn dates were most dissimilar during the consecutive years of El Niño conditions. While $>50 \%$ of the Pacific hake in the 1997 collections were spawned in January, <1 \% of Pacific hake that survived until the spring sampling in 1998 were spawned in January. In contrast, $>60 \%$ of the Pacific hake that survived until spring collections

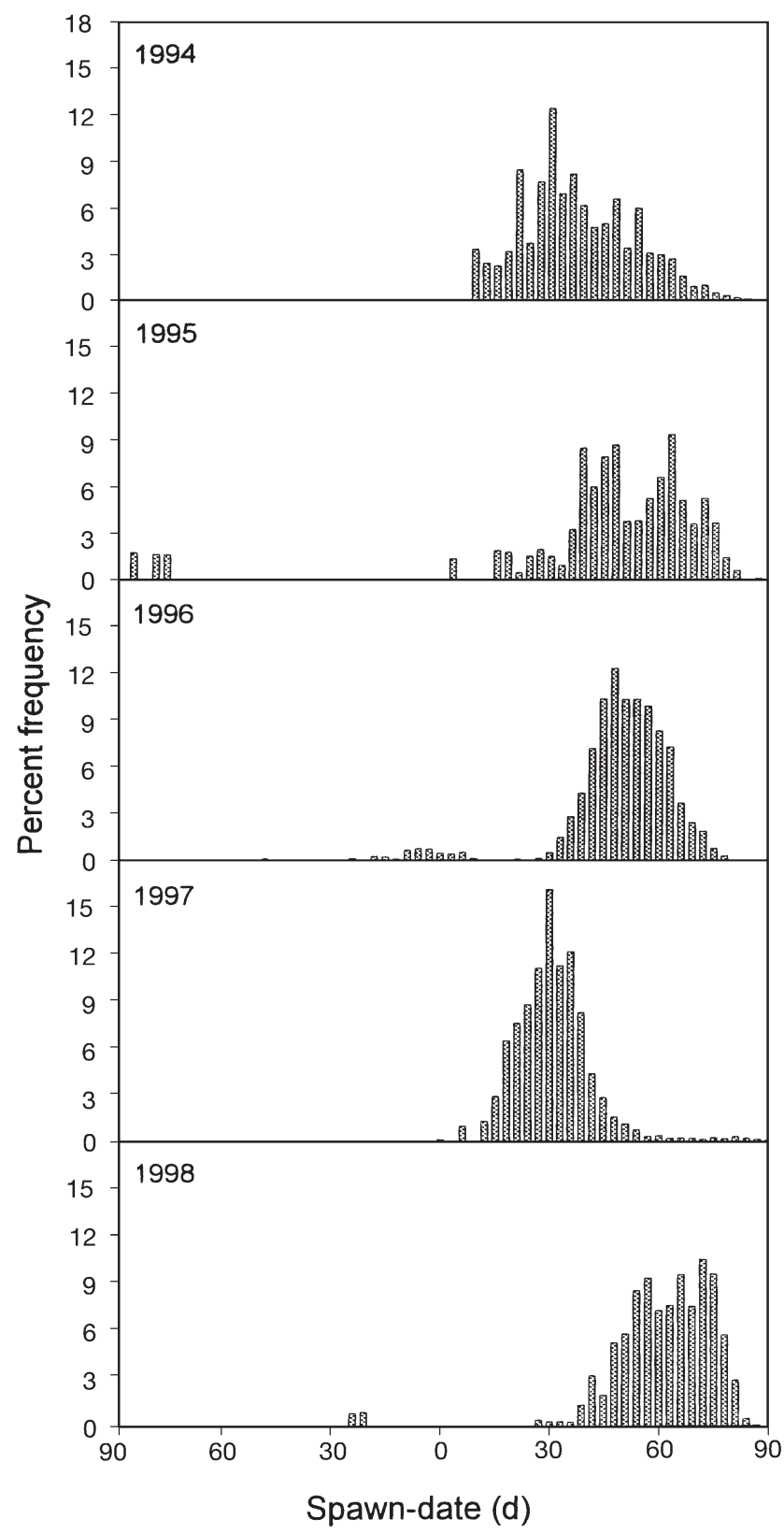

Fig. 4. Merluccius productus. Annual back-calculated spawn date frequency distributions of early juveniles, by year (expressed as calendar dates, relative to 1 January) 
Table 3. Merluccius productus. Summary of the diet of early juveniles, in terms of frequency of occurrence (\%FO), numeric composition $(\% \mathrm{~N})$, and volumetric composition $(\% \mathrm{~V})$, for each mutually exclusive prey category, by year

\begin{tabular}{|c|c|c|c|c|c|c|c|c|c|c|c|c|}
\hline \multirow{2}{*}{ Prey taxa } & \multicolumn{3}{|c|}{1995} & \multicolumn{3}{|c|}{1997} & \multicolumn{3}{|c|}{1998} & \multicolumn{3}{|c|}{1999} \\
\hline & $\% \mathrm{FO}$ & $\% \mathrm{~N}$ & $\% \mathrm{~V}$ & $\% \mathrm{FO}$ & $\% \mathrm{~N}$ & $\% \mathrm{~V}$ & $\% \mathrm{FO}$ & $\% \mathrm{~N}$ & $\% \mathrm{~V}$ & $\% \mathrm{FO}$ & $\% \mathrm{~N}$ & $\% \mathrm{~V}$ \\
\hline Pteropoda & & & & 1.3 & $<0.1$ & $<0.1$ & & & & 1.3 & 0.1 & $<0.1$ \\
\hline Crustacea & 0.7 & 0.1 & $<0.1$ & & & & & & & & & \\
\hline Polyphemidae & 1.4 & 0.1 & $<0.1$ & 0.4 & $<0.1$ & $<0.1$ & & & & 0.4 & $<0.1$ & $<0.1$ \\
\hline Ostracoda & & & & & & & 1.3 & 0.2 & 0.1 & & & \\
\hline Calanoida & 78.2 & 34.2 & 10.8 & 57.6 & 65.1 & 15.9 & 83.9 & 41.9 & 18.2 & 65.4 & 38.3 & 8.1 \\
\hline Calanus pacificus & 85.0 & 51.6 & 33.4 & 43.7 & 13.0 & 6.7 & 85.2 & 35.7 & 36.6 & 54.4 & 9.4 & 12.4 \\
\hline Mesocalanus sp. & 5.4 & 0.7 & 0.3 & & & & 0.9 & 0.2 & 0.2 & 0.4 & 0.1 & $<0.1$ \\
\hline Eucalanus sp. & & & & 0.4 & $<0.1$ & $<0.1$ & 5.2 & 0.9 & 1.7 & 30.8 & 4.2 & 11.5 \\
\hline Rhincalanus sp. & & & & 5.6 & 0.4 & 0.5 & & & & & & \\
\hline Paracalanus sp. & 0.7 & $<0.1$ & $<0.1$ & & & & 5.2 & 1.5 & 0.2 & & & \\
\hline Pseudocalanus sp. & 1.4 & 0.8 & 0.1 & & & & 1.3 & 0.2 & $<0.1$ & 27.4 & 30.0 & 4.6 \\
\hline Clausocalanus sp. & 2.0 & 0.2 & $<0.1$ & 0.4 & $<0.1$ & $<0.1$ & 0.4 & $<0.1$ & $<0.1$ & & & \\
\hline Ctenocalanus sp. & 0.7 & $<0.1$ & $<0.1$ & & & & & & & & & \\
\hline Aetideus armatus & & & & 0.4 & $<0.1$ & $<0.1$ & 0.4 & $<0.1$ & $<0.1$ & & & \\
\hline Euchaeta sp. & & & & & & & & & & 0.4 & $<0.1$ & 0.1 \\
\hline Metridia sp. & 14.3 & 1.5 & 0.4 & 36.8 & 5.6 & 1.7 & 14.4 & 2.6 & 1.3 & 38.8 & 10.5 & 6.0 \\
\hline Pleuromamma sp. & & & & 2.6 & 0.1 & 0.1 & 0.9 & 0.1 & $<0.1$ & 0.8 & 0.1 & 0.1 \\
\hline Acartia sp. & 0.7 & $<0.1$ & $<0.1$ & & & & & & & & & \\
\hline Harpacticoida & & & & & & & & & & 0.4 & $<0.1$ & $<0.1$ \\
\hline Oncaea sp. & & & & & & & 1.3 & 0.2 & $<0.1$ & 0.4 & $<0.1$ & $<0.1$ \\
\hline Corycaeus sp. & & & & 2.2 & 0.1 & $<0.1$ & 0.4 & $<0.1$ & $<0.1$ & 0.4 & $<0.1$ & $<0.1$ \\
\hline Oithona sp. & & & & & & & 0.9 & 0.1 & $<0.1$ & & & \\
\hline Cirripedia & & & & 0.4 & $<0.1$ & $<0.1$ & & & & & & \\
\hline Amphipoda & & & & 1.7 & 0.1 & $<0.1$ & 0.4 & 0.1 & 0.1 & & & \\
\hline Euphausiidae & 2.0 & 0.2 & 2.4 & 22.1 & 1.1 & 11.4 & 18.3 & 3.4 & 12.3 & 40.1 & 2.9 & 23.9 \\
\hline Calyptopis larvae & 6.3 & 1.0 & 0.1 & 14.7 & 2.3 & 0.2 & 3.5 & 0.5 & 0.1 & 3.8 & 0.3 & $<0.1$ \\
\hline Furcilia larvae & 55.8 & 9.0 & 4.9 & 19.1 & 2.1 & 0.6 & 33.9 & 8.0 & 5.1 & 14.8 & 2.6 & 1.3 \\
\hline Euphausia pacifica & 0.7 & $<0.1$ & 2.0 & 37.2 & 4.0 & 49.2 & 23.5 & 4.4 & 23.2 & 14.8 & 1.2 & 28.8 \\
\hline Thysanoessa spinifera & 2.7 & 0.4 & 45.4 & 3.0 & 0.1 & 5.9 & 0.9 & 0.1 & 0.8 & 0.8 & 0.1 & 3.1 \\
\hline Reptantia & 0.7 & $<0.1$ & 0.1 & 15.6 & 1.3 & 4.8 & & & & & & \\
\hline Caridea & & & & 0.4 & $<0.1$ & 0.1 & & & & & & \\
\hline Oikopleura sp. & & & & 9.1 & 4.2 & 2.0 & & & & 0.8 & 0.1 & $<0.1$ \\
\hline Teleostei & & & & 0.4 & $<0.1$ & 0.6 & & & & & & \\
\hline Organic material & & & & 1.7 & 0.1 & 0.1 & & & & & & \\
\hline
\end{tabular}

in 1998 were spawned in March, compared with $<2.5 \%$ in 1997. The distributions of birth dates in 1997 and 1998 were significantly different $(\mathrm{p}<0.001$, Kolmogorov-Smirnov test). The mean spawn date for 1997 was 31.3 calendar d (i.e. 31 January), compared with 60.9 d (i.e. 2 March) for 1998. From 1994 to 1996, mean spawn dates ranged from 36.7 to 49.2 d (i.e 6 February 1994, 13 February 1995, and 18 February 1996).

\section{Composition of diet}

In all years, copepods comprised a dietary staple for early-juvenile Pacific hake. Collectively, they were the most abundantly ingested prey type (Tables 3 \& 4), accounting for 81.0 to $92.6 \% \mathrm{~N}$ of the prey taken each year. As a group, euphausiids were next most abundant, comprising 7.2 to $16.4 \% \mathrm{~N}$ of the diet. 'Other' prey taxa were most important in 1997, when they comprised $9.9 \% \mathrm{~N}$ of the ingested prey, compared with $9.1 \% \mathrm{~N}$ for euphausiids. For all other years, 'other' prey comprised $<1.0 \% \mathrm{~N}$ of ingested prey. While it was not always possible to identify prey to species, most often Calanus pacificus was the dominant copepod in the diet (Tables 3 \& 4, Fig. 5), especially during 1995 and 1998. In 1999, several other copepods were important components of the diet, including the smaller calanoids, Pseudocalanus sp. (at Haul 113) and Metridia sp. (at Hauls 88 and 92). Eucalanus californicus, a calanoid larger than C. pacificus, was dominant at 1 haul in 1999 (Table 5).

In terms of prey volume, the principal component of the diet of early-juvenile Pacific hake shifted from copepods to euphausiids between 30 and $50 \mathrm{~mm}$ SL (Fig. 5). At most hauls Euphausia pacifica was the dominant euphausiid in the diet. The only exceptions occurred when juvenile Pacific hake >80.0 mm SL ingested large volumes of Thysanoessa spinifera at 
Table 4. Merluccius productus. Incidence of feeding and composition of diet of early juveniles, in terms of mean number and width $(\mathrm{mm})$ of prey, number of copepods, euphausiids, and other prey in diet, by size class and year, where $\mathrm{n}=\mathrm{number}$ of specimens examined

\begin{tabular}{|c|c|c|c|c|c|c|c|c|}
\hline Size class & Year & $\mathrm{n}$ & Percent feeding & Mean no. prey & Mean prey width & Copepods & Euphausiids & Other prey \\
\hline \multirow[t]{4}{*}{$10.0-19.9$} & 1995 & 4 & 75.0 & 7.3 & 0.66 & 19 & 3 & 0 \\
\hline & 1997 & 5 & 80.0 & 2.0 & 0.49 & 8 & 0 & 0 \\
\hline & 1998 & 64 & 95.3 & 5.1 & 0.63 & 299 & 9 & 1 \\
\hline & 1999 & 2 & 100.0 & 2.5 & 0.63 & 4 & 1 & 0 \\
\hline \multirow{4}{*}{$20.0-29.9$} & 1995 & 64 & 98.4 & 9.5 & 0.68 & 518 & 80 & 1 \\
\hline & 1997 & 20 & 100.0 & 8.9 & 0.66 & 146 & 27 & 4 \\
\hline & 1998 & 132 & 94.7 & 7.4 & 0.66 & 771 & 158 & 2 \\
\hline & 1999 & 81 & 98.8 & 25.4 & 0.59 & 2005 & 28 & 0 \\
\hline \multirow[t]{4}{*}{$30.0-39.9$} & 1995 & 63 & 98.4 & 15.9 & 0.72 & 897 & 87 & 1 \\
\hline & 1997 & 31 & 87.1 & 42.1 & 0.87 & 1036 & 89 & 13 \\
\hline & 1998 & 42 & 100.0 & 10.0 & 0.76 & 318 & 101 & 1 \\
\hline & 1999 & 108 & 92.6 & 11.9 & 0.79 & 1075 & 109 & 5 \\
\hline \multirow[t]{4}{*}{$40.0-49.9$} & 1995 & 16 & 100.0 & 16.0 & 0.86 & 234 & 22 & 0 \\
\hline & 1997 & 102 & 95.1 & 37.1 & 0.96 & 3230 & 290 & 79 \\
\hline & 1998 & 1 & 100.0 & 11.0 & 0.75 & 6 & 5 & 0 \\
\hline & 1999 & 45 & 93.3 & 9.2 & 0.91 & 321 & 65 & 1 \\
\hline \multirow[t]{3}{*}{$50.0-59.9$} & 1995 & 1 & 0.0 & & & & & \\
\hline & 1997 & 85 & 90.6 & 14.2 & 1.44 & 685 & 154 & 252 \\
\hline & 1999 & 14 & 92.9 & 15.8 & 1.06 & 141 & 65 & 0 \\
\hline \multirow[t]{2}{*}{$60.0-69.9$} & 1997 & 7 & 85.7 & 4.5 & 1.72 & 5 & 18 & 4 \\
\hline & 1998 & 1 & 100.0 & 2.0 & 1.25 & 1 & 1 & 0 \\
\hline$>80.0$ & 1995 & 3 & 100.0 & 3.3 & 3.83 & 0 & 7 & 3 \\
\hline
\end{tabular}

1 haul in 1995, and at 1 haul in 1997, or when euphausiid furcilia larvae were abundantly ingested, at 1 haul in 1995.

Although copepods and euphausiids dominated the diet of early-juvenile Pacific hake, 2 other prey taxa also made important contributions to the diet during the earliest and latest collections in 1997, particularly for Pacific hake $\geq 50.0 \mathrm{~mm}$ SL. Appendicularians (Oikopleura sp.) were ingested by $40 \%$ of the specimens, accounting for $11.3 \% V$ of the diet at 1 haul in 1997 , and in another haul Reptantia (decapod) larvae/earlyjuvenile stages were ingested by $76 \%$ of the specimens, accounting for $49.2 \% \mathrm{~V}$ of the diet.

Significant between-year differences were observed in the distribution of copepods and euphausiids in the diet of 20.0 to $29.9 \mathrm{~mm}$ SL Pacific hake $\left(\chi^{2}=264.13, \mathrm{p}<\right.$ $0.01,3 \mathrm{df}$ ) (Table 4). For larger size classes, comparisons of diet were based on the distribution of cope-
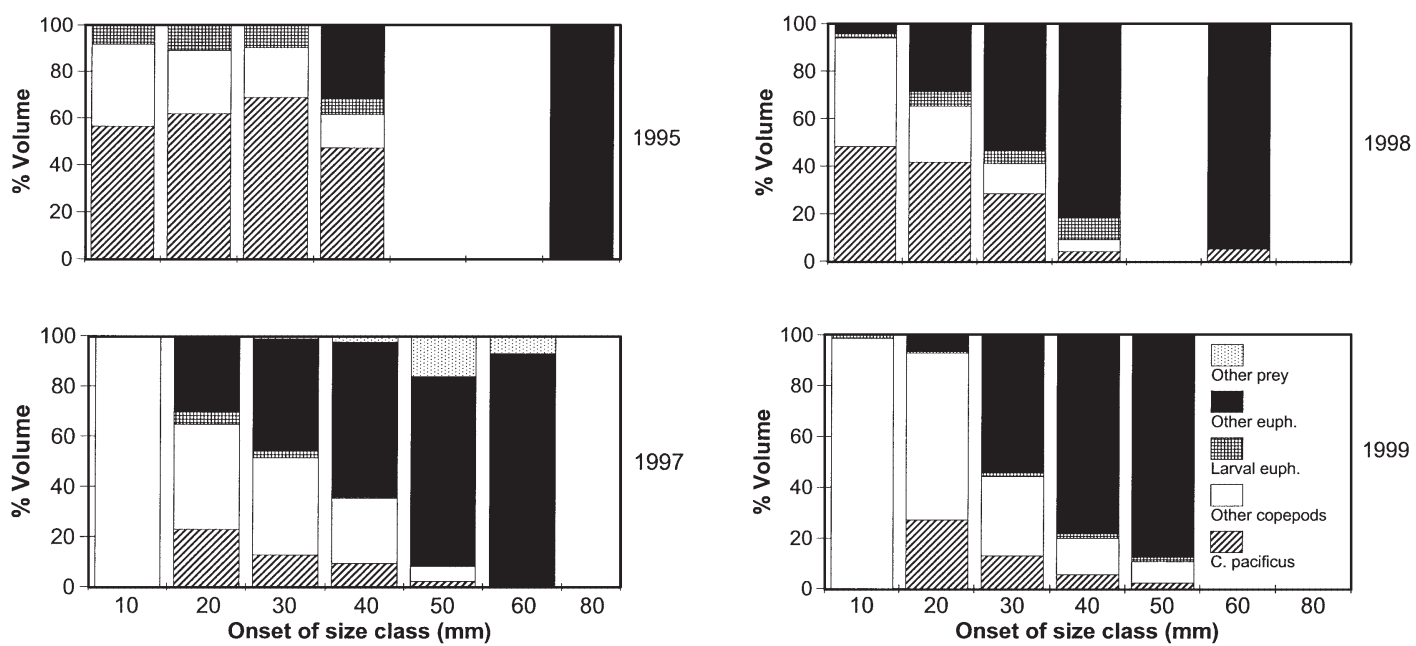

Fig. 5. Merluccius productus. Composition of the diet of early juveniles $(\% \mathrm{~V})$, by year and size class; euph $=$ euphausiids. The range of size classes was $10.0-19.9,20.0-29.9,30.0-39.9,40.0-49.9,50.0-59.9,60.0-69.9$, and $\geq 80.0 \mathrm{~mm}$ SL 


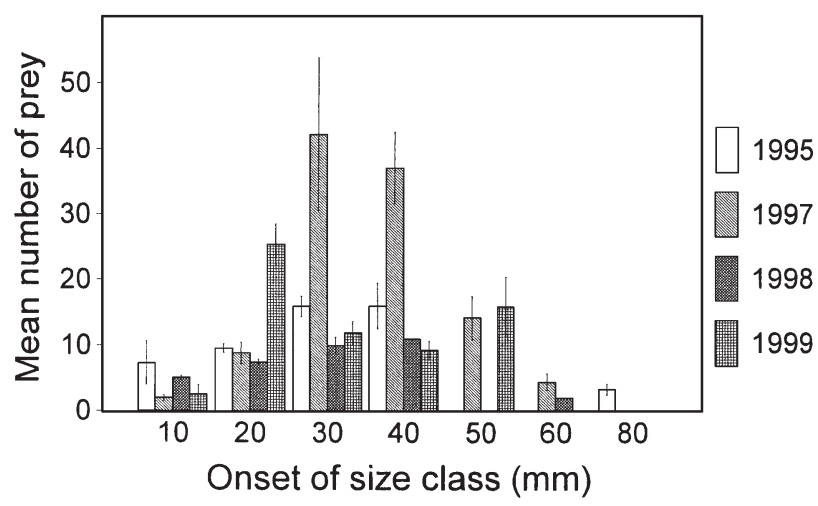

Fig. 6. Merluccius productus. Number of prey (mean $\pm \mathrm{SE}$ ) ingested by early juveniles, by year and size class. Range of size classes as defined in Fig. 5

pods, euphausiids, and 'other' prey in the diet. Significant between-year differences in diet were observed for 30.0 to $39.9 \mathrm{~mm}$ SL Pacific hake $\left(\chi^{2}=108.88, \mathrm{p}<\right.$ $0.01,6 \mathrm{df}$ ), for 40.0 to $49.9 \mathrm{~mm}$ SL Pacific hake (omitting the 1 specimen from 1998) $\left(\chi^{2}=44.09, \mathrm{p}<0.01\right.$, $4 \mathrm{df})$, and for 50.0 to $59.9 \mathrm{~mm}$ SL $\left(\chi^{2}=79.66, \mathrm{p}<0.01\right.$, 2 df). For all size-class comparisons that included 'other' prey, the diet in 1997 contained more 'other' prey than in 1995, 1998, and 1999. In 1999, the diet of 20.0 to 29.9 and 30.0 to $39.9 \mathrm{~mm}$ SL Pacific hake contained more copepods than in 1995, 1997 and 1998.

\section{Number of prey}

Small and large early-juvenile Pacific hake ingested fewer prey than intermediate size classes (Fig. 6). The low number of prey ingested by small individuals was the result of narrow gape and stomach size, while the low number of prey ingested by large individuals was the result of switching to larger prey (e.g. adult euphausiids). An examination of the mean number of prey ingested by Pacific hake each year (Fig. 6, Table 4) revealed that the largest number of prey was ingested in 1997 by Pacific hake ranging from 30.0 to $49.9 \mathrm{~mm}$ SL. Between-collection comparisons in 1997 revealed that large numbers of prey ingested in the earliest collections, Hauls 12 and 24, were responsible for much of the between-year variation. At Haul 12, 9 of 48 specimens $(18.8 \%)$ ingested $>100$ prey, and at Haul 24, 11 of 47 specimens $(23.4 \%$ ) ingested $>100$ prey, including 3 specimens that ingested $>200$ prey items. By contrast, in 1995 and 1998 the maximum number of prey ingested was 59 and 35, respectively, and in 1999 a single fish ingested $>100$ prey. The mean number of prey ingested by Pacific hake 20.0 to 29.9 and 50.0 to $59.9 \mathrm{~mm}$ SL was greatest in 1999 (Fig. 6, Table 4). Based on Kruskal-Wallis 1-way ANOVA for each size class, differences in the number of prey ingested between years were significant $(\mathrm{p}=$ 0.05 ) only for the 20.0 to 29.9 and 30.0 to $39.9 \mathrm{~mm} \mathrm{SL}$ size classes.

Table 5. Merluccius productus. Size of early juveniles. Mean, minimum, and maximum standard length; incidence of feeding, mean number of prey items, and principal prey ingested $(\% \mathrm{~V})$, by year and haul, with $\mathrm{n}=$ number of specimens examined.

Note: two or more prey items were listed when prey volumes differed by less than $5 \%$. Dates are presented as mo/d/yr

\begin{tabular}{|c|c|c|c|c|c|c|c|c|c|}
\hline \multirow[t]{2}{*}{ Year } & \multirow[t]{2}{*}{ Haul } & \multirow[t]{2}{*}{ Date } & \multirow[t]{2}{*}{$\mathrm{n}$} & \multicolumn{3}{|c|}{ Standard length (mm) } & \multirow{2}{*}{$\begin{array}{c}\text { Feeding } \\
(\%)\end{array}$} & \multirow{2}{*}{$\begin{array}{c}\text { Mean no } \\
\text { prey }\end{array}$} & \multirow[t]{2}{*}{ Principal prey } \\
\hline & & & & Mean & Min. & Max. & & & \\
\hline \multirow[t]{5}{*}{1995} & 1 & $5 / 17 / 95$ & 4 & 80.4 & 47.9 & 93.2 & 100.0 & 2.8 & Thysanoessa spinifera \\
\hline & 10 & $5 / 19 / 95$ & 19 & 30.6 & 18.0 & 41.1 & 94.7 & 7.6 & Euphausia pacifica, Calanus pacificus \\
\hline & 11 & 5/19/95 & 10 & 25.6 & 22.7 & 33.8 & 100.0 & 9.1 & C. pacificus, euphausiid furcilia \\
\hline & 40 & $5 / 26 / 95$ & 3 & 34.3 & 28.1 & 40.5 & 66.7 & 14.0 & Euphausiidae \\
\hline & 53 & $5 / 27 / 95$ & 115 & 32.4 & 20.1 & 48.5 & 98.3 & 14.2 & C. pacificus \\
\hline \multirow[t]{5}{*}{1997} & 12 & $5 / 16 / 97$ & 50 & 36.8 & 16.7 & 58.3 & 98.0 & 50.5 & Calanoida, E. pacifica, C. pacificus \\
\hline & 24 & $5 / 18 / 97$ & 50 & 46.1 & 35.0 & 57.7 & 96.0 & 61.1 & E. pacifica, Calanoida \\
\hline & 40 & $5 / 20 / 97$ & 50 & 45.3 & 20.4 & 61.8 & 100.0 & 7.0 & E. pacifica \\
\hline & 74 & $5 / 26 / 97$ & 50 & 48.0 & 28.0 & 66.8 & 92.0 & 2.8 & E. pacifica \\
\hline & 223 & $6 / 15 / 97$ & 50 & 52.1 & 23.2 & 66.8 & 76.0 & 4.1 & Reptantia larvae/juveniles \\
\hline \multirow[t]{4}{*}{1998} & 108 & $5 / 16 / 98$ & 60 & 21.3 & 16.0 & 29.3 & 86.7 & 4.5 & C. pacificus \\
\hline & 143 & $5 / 24 / 98$ & 60 & 32.0 & 23.1 & 68.1 & 100.0 & 10.6 & C. pacificus \\
\hline & 178 & $5 / 29 / 98$ & 60 & 19.9 & 13.5 & 29.6 & 96.7 & 6.3 & C. pacificus \\
\hline & 181 & $5 / 30 / 98$ & 60 & 24.3 & 15.8 & 36.7 & 100.0 & 7.3 & C. pacificus, E. pacifica \\
\hline \multirow[t]{5}{*}{1999} & 86 & 5/29/99 & 50 & 33.7 & 22.4 & 56.3 & 90.0 & 5.4 & Euphausiidae, E. pacifica \\
\hline & 88 & $5 / 30 / 99$ & 50 & 37.0 & 24.6 & 56.1 & 98.0 & 13.2 & E. pacifica \\
\hline & 92 & 5/30/99 & 50 & 39.8 & 19.6 & 56.5 & 96.0 & 12.6 & E. pacifica, Euphausiidae \\
\hline & 107 & 6/01/99 & 50 & 31.6 & 18.2 & 42.2 & 90.0 & 3.8 & Eucalanus sp. \\
\hline & 113 & 6/03/99 & 50 & 29.7 & 21.1 & 41.4 & 100.0 & 43.1 & Euphausiidae, Pseudocalanus sp. \\
\hline
\end{tabular}




\section{Size of prey}

The differences in prey numbers observed between years can be only partly attributed to the mean width of ingested prey (Fig. 7). In 1999, the diet of 20.0 to $29.9 \mathrm{~mm}$ SL Pacific hake demonstrated the anticipated relationship between a large number of ingested prey and small mean prey size (Figs. 6 \& 7, Table 4). However, in 1997, while Pacific hake in the 30.0 to 39.9 and 40.0 to $49.9 \mathrm{~mm}$ SL size classes ingested the greatest numbers of prey, compared with other years, mean prey widths were not the smallest. Early-juvenile Pacific hake ingested a wider range of prey sizes in 1997 than in all other years (Fig. 7). In 1997, Pacific hake abundantly ingested both small prey and some larger prey. Substantial between-haul variation in size of ingested prey was seen in 1997. Ingested prey were smaller at Haul 12 in 1997, while at Hauls 74 and 223, prey were larger. The smaller prey included euphausiid calyptopis larvae, and some calanoid and poecilostomatoid copepods.

\section{Incidence of feeding}

Incidence of feeding varied little between years of collection, ranging from $92.4 \%$ in 1997 to $97.4 \%$ in 1995 (Table 5). Between-year differences in the incidence of feeding were not significant $\left(\chi^{2}=5.47, \mathrm{p}=\right.$ $0.14,3 \mathrm{df}$ ), although some differences were observed within years. In 1997, the year with the lowest incidence of feeding, between-size-class differences (after pooling size classes into $20 \mathrm{~mm}$ increments to remove bias associated with a large number of very low expected values for 'empty' stomachs) in the incidence of feeding were not significant $\left(\chi^{2}=1.22, p=0.54,2 \mathrm{df}\right)$. However, between-haul differences were observed in 1997. The incidence of feeding was significantly lower in Haul 223 than in all other hauls $\left(\chi^{2}=23.94, \mathrm{p}<0.01\right.$, $1 \mathrm{df}$ ), with $24 \%$ empty stomachs (Table 5). Haul 223, the latest collection, contained the largest specimens. These would be the most capable of withstanding periods of prey shortages.

\section{DISCUSSION}

Oceanographic conditions off California during late winter and early spring largely shape the strength of Pacific hake year classes. A complex milieu of physical and biological parameters contributes to recruitment success. Much of the interannual variability in Pacific hake recruitment is determined by oceanographic conditions in coastal nursery habitats during the first few months of life (Hollowed 1992). Short-term, epi-

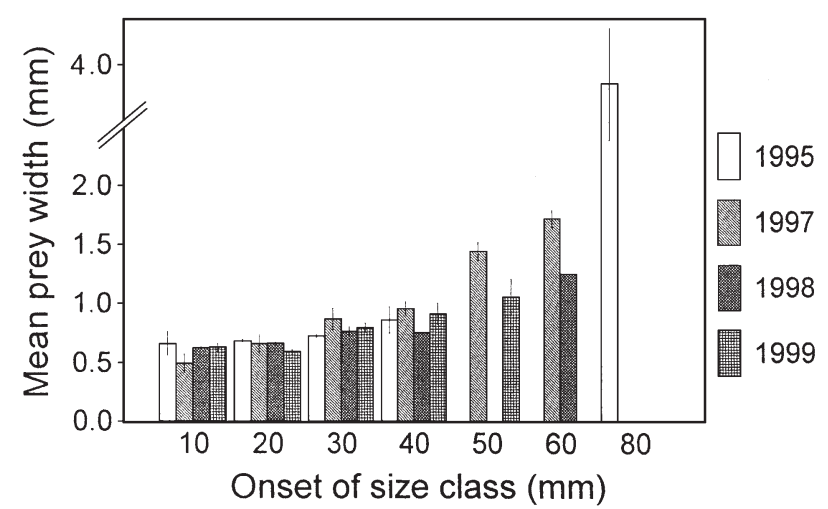

Fig. 7. Merluccius productus. Widths of prey (mean \pm SE) ingested by early juveniles, by year and size class. Range of size classes as defined in Fig. 5

sodic changes in oceanographic conditions can impact Pacific hake year classes as well as longer-term changes such as El Niño events or regime shifts.

Owing to the capabilities of juvenile Pacific hake to migrate into or out of survey areas, the abundance estimates are useful in a relative rather than absolute sense. Over the course of $14 \mathrm{yr}$ of surveys, the lowest catches of juvenile Pacific hake occurred in 1995, when intense southerly storms, which resulted in strong downwelling, coincided with peak spawning of Pacific hake. Oceanographic conditions off California in January and February 1995 were characterized by SSTs that were 0.6 to $2.4^{\circ} \mathrm{C}$ above normal, with strong downwelling (negative upwelling) in January and anomalously low upwelling in February ${ }^{2}$. While warm ocean conditions and/or low upwelling tend to favor larval Pacific hake survival (Bailey 1981, Bailey \& Francis 1985), in 1995, these conditions were not followed by the third prerequisite for a strong year class: strong upwelling in March (Hollowed \& Bailey 1989). ${ }^{3}$ January's storm-induced downwelling in concert with low upwelling in March, resulted in the smallest catch of juvenile Pacific hake in May 1995. The second lowest catch of juvenile Pacific hake occurred during spring of the 1998 El Niño event.

Part of the difference in the biotic environment during the 2 consecutive years of El Niño conditions can be attributed to differences in nutrient-rich upwelling

\footnotetext{
${ }^{2}$ El Niño watch, advisory 1995-01, 1995-02, and 1995-03. Coastal ocean mean SST $(\% \mathrm{C})$ and deviation from normal, January 1995, February 1995 and March 1995. NOAA/NESDIS, CoastWatch, La Jolla, CA

${ }^{3}$ El Niño watch, advisory 1997-02, 1997-03, 1997-04, 1997-05, and 1997-06. Coastal ocean mean SST $\left({ }^{\circ} \mathrm{C}\right)$ and deviation from normal, February 1997, March 1997, April 1997, May 1997, and June 1997. NOAA/NESDIS, CoastWatch, La Jolla, CA
} 
between 1997 and 1998. At 33 $\mathrm{N}$ latitude (in the historical spawning grounds of Pacific hake), during the first half of 1997, positive upwelling anomalies occurred during February and April, and negative upwelling anomalies occurred in March, May and June 1997. During this same period in 1998, a small positive upwelling anomaly occurred in February, and negative upwelling anomalies occurred from March through June 1998 (Hayward 2000). In the present study area, just off the coast at $37^{\circ} \mathrm{N}$ latitude, from February through June 1997, upwelling anomalies were $+3.5,+1.7,+1.2,-1.7$, and +1.5 standard deviation (SD) units, and SST anomalies were $+2.5,-1.5$, $-1.5,0.0$, and $+0.0^{\circ} \mathrm{C}$, respectively ${ }^{3}$. From February through June 1998, less upwelling occurred compared to 1997, with upwelling anomalies of $-1.0,+0.8,-0.2$, -1.7 , and $-1.0 \mathrm{SD}$ units, and water was warmer than in 1997, with SST anomalies of $+1.5,+1.0,+1.0,+1.5$, and $+1.5^{\circ} \mathrm{C}$, respectively ${ }^{4}$. During spring of 1997 , the multivariate El Niño Southern Oscillation Index (MEI) increased from about 0.3 in March to about 1.8 in May. The MEI stayed at values above 2.0 from June 1997 into May of 1998 (Hayward et al. 1999). In contrast, at $37^{\circ} \mathrm{N}$ latitiude, during La Niña conditions in spring 1999, strong upwelling dropped water temperatures. From February through June, the upwelling anomalies were $+0.7,+0.7,+2.2,+2.5$, and $+2.0 \mathrm{SD}$ units, and SST anomalies were $-1.0,-1.0,-2.0,-3.0$, and $-2.5^{\circ} \mathrm{C}$, respectively ${ }^{5}$. During February through June 1999, MEI values ranged from -1.0 to -0.4 (Bograd et al. 2000).

The 1997 El Niño year class of Pacific hake was not exceptional in size, ranking ninth largest in $14 \mathrm{yr}$ of juvenile collections. This nearly median-sized Pacific hake year class apparently mitigated anomalous ocean conditions via opportunistic food choices. In some cases, large numbers of small prey were ingested, and in other cases atypical prey taxa were consumed. Frequently, large prey were also abundantly ingested. In 1997, early-juvenile Pacific hake ingested the widest range of prey sizes. While the diet varied from site to site, high primary production due to heavy upwelling early in the El Niño conditions apparently formed the basis for a food chain sufficient to sustain the year class.

${ }^{4}$ El Niño watch, advisory 1998-02, 1998-03, 1998-04, 1998-05, and 1998-06. Coastal ocean mean SST $\left({ }^{\circ} \mathrm{C}\right)$ and deviation from normal, February 1998, March 1998, April 1998, May 1998, and June 1998. NOAA/NESDIS, CoastWatch, La Jolla, CA

${ }^{5}$ El Niño watch, advisory 1999-02, 1999-03, 1999-04, 1999-05, and 1999-06. Coastal ocean mean SST (\%C) and deviation from normal, February 1999, March 1999, April 1999, May 1999, and June 1999. NOAA/NESDIS, CoastWatch, La Jolla, CA
In contrast, the second consecutive year of El Niño conditions, 1998, appears to have been more debilitating to early-juvenile Pacific hake than the first year. Differential effects of the 2 El Niño years were manifested in the size distributions of early-juvenile Pacific hake in spring collections. In 1997, $10.0 \%$ of Pacific hake were $<30.0 \mathrm{~mm}$, and $77.6 \%$ were $\geq 40 \mathrm{~mm}_{\text {i }}$ while in $1998,81.7 \%$ of Pacific hake were $<30.0 \mathrm{~mm}$, and $0.8 \%$ were $\geq 40 \mathrm{~mm}$ SL. Every effort was made to examine large specimens in 1998, but they were essentially absent from the collections. A comparison of spawndate distributions in 1997 and 1998 reveals that survival from early spawns in 1998 was extremely poor. During the February 1998 CalCOFI cruise, the frequency of occurrence and average abundance of larval Pacific hake were anomalously low relative to other years, including 1997 (G. Moser pers. comm.). Clearly, El Niñoinduced oceanographic conditions in early 1998 were detrimental to larval and early-juvenile Pacific hake.

An examination of growth rates and spawn dates in 1987, 1988, 1991 and 1992 (Woodbury et al. 1995) revealed that early-juvenile Pacific hake grew slowly, and were least abundant during the 1992 El Niño event, compared with years of non-anomalous conditions. Survival from early spawning in 1992 was also poor. Reduced abundance of Pacific hake in 1992 may have resulted from increased larval mortality or advection of larvae outside the study area, due to increased poleward flow of currents during the El Niño conditions (Woodbury et al. 1995).

In contrast, in the present study, growth rates were highest during 1997, the first year of El Niño conditions, but Pacific hake were most abundant during 1999, the year of La Niña conditions. Although a comparison of growth rates from the 2 years of El Niño conditions, 1997 and 1998, supports the conclusion reached in the earlier study that growth rates are slower during years of low abundance and faster during years of high abundance (Woodbury et al. 1995), this comparison does not hold up between all year pairs. One caveat that should be considered is that few Pacific hake older than $110 \mathrm{~d}$ were available for age and growth analysis in 1998, relative to other years. The vast majority of the specimens from 1998 that were used in the growth analysis were spawned, or started feeding, after the depauperate plankton conditions of February 1998. Unfortunately, growth data for 1999, the La Niña year, were not available for comparison.

Nutrient-regulated biological production in the southern California Current System was severely affected by El Niño conditions in 1998. Very deep (>80 m) nutriclines reduced the availability of nutrients to the euphotic zone all the way to the coast, particularly in February 1998 (Bograd \& Lynn 2001). The ensuing biological drought lasted several months. The 
biomass of macrozooplankton off California in late winter and spring of 1998 was lowest in the entire CalCOFI time series of cruise data (1951 to present) (Lynn et al. 1998, Hayward 2000). Thus, food limitation may have been a major determinant of year-class strength for 1998. Early in 1998, sub-optimal diet and/or reduced incidence of feeding, in concert with warm sea temperatures in coastal habitats, apparently resulted in reduced rates of growth and survival for larval and early-juvenile Pacific hake. By the time of the spring collections, in May, a food chain adequate to support a small year class of Pacific hake had developed.

During non-anomalous ocean conditions, the diet of early-juvenile Pacific hake progresses from copepods to euphausiids (Livingston \& Bailey 1985). Calanus pacificus, the dominant copepod species in the diet of Pacific hake in this study, is an abundant copepod species that is widely distributed in the California Current system. A substantial reduction of egg production and over-wintering females of $C$. pacificus occurred during El Niño conditions in winter-spring 1992 and 1993 (Mullin 1995a, 1997). Abundance and survival of $C$. pacificus nauplii were also reduced by the 1992-1993 El Niño conditions (Mullin 1995b, 1997). In 1993, judging from their abundance in spring collections, larval and early-juvenile Pacific hake were able to overcome the scarcity of this key prey species. However, in late winter and early spring 1998, larval and early-juvenile Pacific hake likely encountered diminished production of C. pacificus as well as a virtual absence of alternative zooplankton prey. These El Niño-induced conditions appear to have been detrimental to the growth and survival of larval and early-juvenile Pacific hake early in 1998.

Euphausiids constitute a dietary staple for Pacific hake 5 to $45 \mathrm{~cm}$ SL (Livingston \& Bailey 1985, Buckley \& Livingston 1997). Although the distribution of some euphausiid species is altered in response to El Niño events (Brinton 1981, Brodeur 1986), the effect of winter El Niño conditions on euphausiid distribution in a second consecutive El Niño spring is unclear. In one of the few studies to consider the influence of interannual variations in ocean conditions on the biology of euphausiids, Tanasichuk (1998a) found that Euphausia pacifica productivity peaked during 1992 and 1993 El Niño conditions, off Vancouver Island, in response to strong upwelling. At the same time, the response of Thysanoessa spinifera populations to changes in ocean conditions was quite different from E. pacifica: both larvae and adults peaked in abundance in 1992, and then declined to pre-El Niño levels in 1993 and 1994, likely in response to predation pressure from Pacific hake (Tanasichuk 1998b). In the California Current, E. pacifica, a cool-water species, declined from high levels in 1996 to nearly normal levels in 1997. During
1998, E. pacifica populations declined to their lowest level on record, and then increased in response to the La Niña conditions in 1999 (Hayward 2000). On the other hand, Nyctiphanes simplex, a warm-water species, was not abundant in the California Current during 1997, but became quite abundant in spring of 1998, then returned to normal low abundance in 1999 (Hayward 2000).

The principal difference in diet between the El Niño years and 1999, the La Niña year, was observed in the diet of 20.0 to $29.9 \mathrm{~mm}$ SL Pacific hake. A larger number of smaller prey were ingested during the La Niña year. Smaller calanoid copepods, Metridia sp. and Pseudocalanus sp., were more important during 1999, compared with the El Niño years. Farther north in the Pacific Ocean off North America, during previous El Niño events, small copepods replaced large copepods from lat. $40^{\circ} \mathrm{N}$ to $52^{\circ} \mathrm{N}$ (Fulton \& LeBrasseur 1985); and other fish species ingested smaller copepods (Grover \& Olla 1987). Fulton \& LeBrasseur (1985) suggested that the absence of large copepods and decreased biomass of zooplankton during an earlier El Niño may have resulted in reduced growth and survival of juvenile salmonids. However, in the present study, the dietary shift to smaller copepods that occurred during $1999 \mathrm{La}$ Niña-conditions, did not correspond with decreased zooplankton production, which occurred in spring 1998 (Lynn et al. 1998, Hayward 2000). It is unclear what impact ingesting smaller copepods might have had on early-juvenile Pacific hake during 1999, as growth rates were not available for 1999.

Although larval and early-juvenile Pacific hake are clearly vulnerable to El Niño-induced oceanographic anomalies, the effects of El Niño conditions on this species are not limited to the early stages. Due to a complex life history that includes long-distance migrations to and from spawning grounds (Alverson \& Larkins 1969) and diurnal migrations through the water column following vertical migrations of prey populations (Alton \& Nelson 1970), Pacific hake experience the effects of El Niño events through all stages (Bailey \& Incze 1985, Bailey \& Francis 1986, Brodeur 1986, Rexstad \& Pikitch 1986, Alados et al. 1993, Dorn 1995, MacLellan \& Saunders 1995, McFarlane et al. 2000).

By any standards, the 1997-1998 El Niño was a very large event, having a world-wide impact (Freeland 1999). Pacific hake were effected by the anomalous conditions throughout their range, and through all life stages. However, the greatest impact of the recent El Niño event on Pacific hake may have occurred during the 3 mo following spawning in 1998, for 2 reasons: (1) much of the variability in recruitment is determined by oceanographic conditions in nursery habitats during this period (Hollowed \& Bailey 1989, Hollowed 1992), and (2) oceanographic conditions were biologi- 
cally poor, i.e. record low levels of macrozooplankton biomass were observed in February and April of 1998 (Lynn et al. 1998, Hayward et al. 1999, Bograd et al. 2000, Hayward 2000, Bograd \& Lynn 2001), resulting in reduced survival from early spawns.

Acknowledgements. We would like to thank Pat Livingston of the AFSC for her continued interest in this project, Steve Ralston of the SWFSC for his assistance with data and analyses, and Craig Toll of HMSC for his help with graphics. We also gratefully acknowledge the assistance of the officers and crew of the NOAA RV 'David Starr Jordan', and all the scientists of the NMFS Tiburon Laboratory who participated in collecting the specimens used in this study. This work was partially supported by grant no. NA76RG0476 (project no. R/HAB-01-PD) from the National Oceanic and Atmospheric Administration to the Oregon State University Sea Grant College Program and by appropriations made by the Oregon State legislature. The views expressed herein are those of the authors and do not necessarily reflect the views of NOAA or any of its subagencies.

\section{LITERATURE CITED}

Alados CL, Escos J, Emlen JM (1993) Developmental instability as an indicator of environmental stress in the Pacific hake (Merluccius productus). Fish Bull US 91:587-593

Alton MS, Nelson MO (1970) Food of Pacific hake, Merluccius productus, in Washington and northern Oregon coastal waters. US Fish Wildl Serv Circ 332:35-42

Alverson DL, Larkins HA (1969) Status of the knowledge of the Pacific hake resource. Calif Coop Ocean Fish Invest Rep 12-24:31

Bailey KM (1981) Larval transport and recruitment of Pacific hake Merluccius productus. Mar Ecol Prog Ser 6:1-9

Bailey KM (1982) The early life history of the Pacific hake, Merluccius productus. Fish Bull US 80:589-598

Bailey KM, Francis RC (1985) Recruitment of Pacific whiting, Merluccius productus, and the ocean environment. Mar Fish Rev 47(2):8-15

Bailey KM, Francis RC (1986) Environment and population dynamics of Pacific whiting, Merluccius productus. Bull Int North Pac Fish Comm 45:317-333

Bailey KM, Incze LS (1985) El Niño and the early life history and recruitment of fishes in temperate marine waters. In: Wooster WS, Fluharty DK (eds) El Niño north: Niño effects in the eastern subarctic Pacific Ocean. Washington Sea Grant Program, WSG-WO 85-03, Seattle, p 143-165

Bailey KM, Francis RC, Stevens PR (1982) The life history and fishery of Pacific whiting Merluccius productus. Calif Coop Ocean Fish Invest Rep 23:81-98

Bograd SJ, Lynn RJ (2001) Physical-biological coupling in the California Current during the 1997-99 El Niño-La Niña cycle. Geophys Res Lett 28:275-278

Bograd SJ, Digiacomo PM, Durazo R, Hayward TL and 8 others (2000) The state of the California Current, 1999-2000: forward to a new regime? Calif Coop Ocean Fish Invest Rep 41:26-52

Brinton E (1981) Euphausiid distributions in the California Current during the warm winter-spring of 1977-1978, in the context of a 1949-1966 time series. Calif Coop Ocean Fish Invest Rep 22:135-154

Brodeur RD (1986) Northward displacement of the euphausiid Nyctiphanes simplex Hansen to Oregon and Washington waters following the El Niño event of 1982-83. J Crustac Biol 6:686-692

Buckley TW, Livingston PA (1997) Geographic variation in the diet of Pacific Hake, with a note on cannibalism. Calif Coop Ocean Fish Invest Rep 38:53-62

Conover WJ (1980) Practical nonparametric statistics, 2nd edn. Wiley \& Sons, New York

Dorn MW (1995) The effects of age composition and oceanographic conditions on the annual migration of Pacific whiting, Merluccius productus. Calif Coop Ocean Fish Invest Rep 36:97-105

Dorn MW, Methot RD (1990) Status of the Pacific whiting resource in 1989 and recommendations to management in 1990. NOAA Tech Memo NMFS F/NWC-182

Dorn MW, Saunders MW (1997) Status of the coastal Pacific whiting stock in US and Canada in 1997. Appendix Vol 1. In: Status of the Pacific coast ground fish fishery through 1997 and recommended acceptable biological catches in 1998: stock assessment and fishery evaluation. Pac Fish Manage Counc, Portland, OR

Fiedler PC (1984) Satellite observations of the 1982-1983 El Niño along the US Pacific Coast. Science 224:1251-1254

Freeland H (1999) Preface. Proc 1998 Sci Board Symp impacts of the 1997/1998 El Niño event on the north Pacific Ocean and its marginal seas. PICES Sci Rep10:v-vi

Freeland H (2000) The 1997-98 El Niño: the view from Line P. Calif Coop Ocean Fish Invest Rep 41:56-61

Fulton JD, LeBrasseur RJ (1985) Interannual shifting of the subarctic boundary and some of the biotic effects on juvenile salmonids. In: Wooster WS, Fluharty DK (eds) El Niño north: Niño effects in the eastern subarctic Pacific Ocean. Washington Sea Grant Program, WSG-WO 85-03, Seattle, p 237-247

Grover JJ, Olla BL (1987) Effects of an El Niño event on the food habits of larval sablefish, Anoplopoma fimbria, off Oregon and Washington. Fish Bull US 85:71-79

Hayward TL (2000) El Niño 1997-98 in the coastal waters of southern California: a timeline of events. Calif Coop Ocean Fish Invest Rep 41:98-116

Hayward TL, Mantyla AW, Lynn RJ, Smith PE, Chereskin TK (1994) The state of the California Current in 1993-1994. Calif Coop Ocean Fish Invest Rep 35:19-35

Hayward TL, Baumgartner TR, Checkley DM, Durazo R and 8 others (1999) The state of the California Current in 19981999: transition to cool-water conditions. Calif Coop Ocean Fish Invest Rep 40:29-82

Hollowed AB (1992) Spatial and temporal distributions of Pacific hake, Merluccius productus, larvae and estimates of survival during early life stages. Calif Coop Ocean Fish Invest Rep 33:100-123

Hollowed AB, Bailey KM (1989) New perspectives on the relationship between recruitment of Pacific hake Merluccius productus and the ocean environment. In: Beamish RJ, McFarlane GA (eds) Effects of ocean variability on recruitment and an evaluation of parameters used in stock assessment models. Special Publ Can Fish Aquat Sci 108:207-220

Hunter JR, Hollowed AB (1997) The 1996 hake symposium. Calif Coop Ocean Fish Invest Rep 38:51-52

Huyer A, Smith RL (1985) The signature of El Niño off Oregon, 1982-1983. J Geophys Res C 90:7133-7142

Livingston PA, Bailey KM (1985) Trophic role of the Pacific whiting, Merluccius productus. Mar Fish Rev 42(2):16-22

Lynn RJ, Baumgartner T, Garcia J, Collins CA and 8 others (1998) The state of the California Current, 1997-1998: transition to El Niño conditions. Calif Coop Ocean Fish Invest Rep 39:25-49 
MacLellan SE, Saunders MW (1995) A natural tag on the otoliths of Pacific hake (Merluccius productus) with implications for age validation and migration. Belle W Baruch Libr Mar Sci 19:567-580

McFarlane GA, King JR, Beamish RJ (2000) Have there been recent changes in climate? Ask the fish. Prog Oceanogr 47:147-169

McGowan JA (1985) El Niño in the Southern California Bight. In: Wooster WS, Fluharty DK (eds) El Niño north: Niño effects in the eastern subarctic Pacific Ocean. Washington Sea Grant Program, WSG-WO 85-03, Seattle, p 166-184

Methot RD, Dorn MW (1995) Biology and fisheries of North Pacific hake (M. productus). In: Alheit J, Pitcher TJ (eds) Hake: biology, fisheries and markets. Chapman \& Hall, London, p 389-414

Mullin MM (1995a) The Californian El Niño of 1992 and the fall of Calanus. Calif Coop Ocean Fish Invest Rep 36: $175-178$

Mullin MM (1995b) Nauplii of the copepod, Calanus pacificus, off southern California in the El Niño winter-spring of 1992, and implications for larval fish. J Plankton Res 17(1):183-189

Mullin MM (1997) The demography of Calanus pacificus during winter-spring Californian El Niño conditions, 19921993: implications for anchovy? Fish Oceanogr 6:10-18

Peterson WT (1999) Hydrography and zoooplankton off the central Oregon coast during the 1997-1998 El Niño event. Proc 1998 Sci Board Symp impacts of the 1997/98 El Niño event on the north Pacific Ocean and its marginal seas. PICES Sci Rep 10:45-50

Rexstad EA, Pikitch EK (1986) Stomach contents and food

Editorial responsibility: Otto Kinne (Editor),

Oldendorf/Luhe, Germany consumption estimates of Pacific hake, Merluccius productus. Fish Bull US 84:947-956

Sakuma KM, Ralston S (1997) Vertical and horizontal distribution of juvenile Pacific whiting (Merluccius productus) in relation to hydrography off California. Calif Coop Ocean Fish Invest Rep 38:137- 146

Stauffer GD (1985) Biology and life history of the coastal stock of Pacific whiting, Merluccius productus. Mar Fish Rev $47(2): 2-7$

Tanasichuk RW (1998a) Interannual variations in the population biology and productivity of Euphausia pacifica in Barkley Sound, Canada, with special reference to the 1992 and 1993 warm ocean years. Mar Ecol Prog Ser 173: $163-180$

Tanasichuk RW (1998b) Interannual variations in the population biology and productivity of Thysanoessa spinifera in Barkley Sound, Canada, with special reference to the 1992 and 1993 warm ocean years. Mar Ecol Prog Ser 173: 181-195

Woodbury D, Ralston S (1991) Interannual variation in growth rates and back-calculated birthdate distributions of pelagic juvenile rockfishes (Sebastes spp.) off the central California coast. Fish Bull US 89:523-533

Woodbury D, Hollowed AB, Pearce JA (1995) Interannual variation in growth rates and back-calculated spawn dates of juvenile Pacific hake (Merluccius productus). Belle W Baruch Libr Mar Sci 19:481-496

Wyllie Escheverria T, Lenarz WH, Reilly C (1990) Survey of the abundance and distribution of pelagic young-of-theyear rockfishes off central California. NOAA Tech Memo NMFS-SWFC-147

Submitted: July 10, 2001; Accepted: March 21, 2002

Proofs received from author(s): August 22, 2002 